Images in...

\title{
Optic nerve involvement as a first manifestation of acute lymphoblastic leukaemia after remission
}

\author{
Mohammadreza Peyman, Thomas Law Ngo Hieng, Visvaraja Subrayan
}

University of Malaya, Kuala Lumpur, Malaysia

Correspondence to Mohammadreza Peyman, drmpeyman@yahoo.com

\section{DESCRIPTION}

A 20-year-old girl with acute lymphoblastic leukaemia in second remission for 4 years, presented with blurring of vision and binocular diplopia for 2 months duration. Examination revealed isolated left 6 th cranial nerve palsy. Fundus showed swollen both optic disc and fan-shaped macular star suggestive of papilloedema. CT scan and MRI of brain revealed no space occupying lesion or hydrocephalus. However the presence of peripapillary yellowish infiltrates raised suspicion of leukaemic infiltrates (figures 1 and 2). Lumbar puncture revealed numerous blast cells. Bone marrow biopsy also showed frank relapse with precursor B cells acute lymphoblastic leukaemia. Leukaemic optic disc infiltration is rare and may mimic papilloedema. ${ }^{1}$ Presence of yellowish peripapillary infiltrates ${ }^{2}$ should alert attending physician to proceed with lumbar puncture to confirm the diagnosis of a relapse. This patient underwent systemic and intrathecal chemotherapy.

Competing interests None.

Patient consent Obtained.

\section{REFERENCES}

1. Merle H, Richer R, Donnio A, et al. [Leukemic infiltration of the optic nerve]. J Fr Ophtalmol 2006;29:e25.

2. De Laey JJ, De Gersem R. [Clinical aspects of leukemic infiltration of the choroid and the optic nerve]. J Fr Ophtalmol 1989;12:819-25.

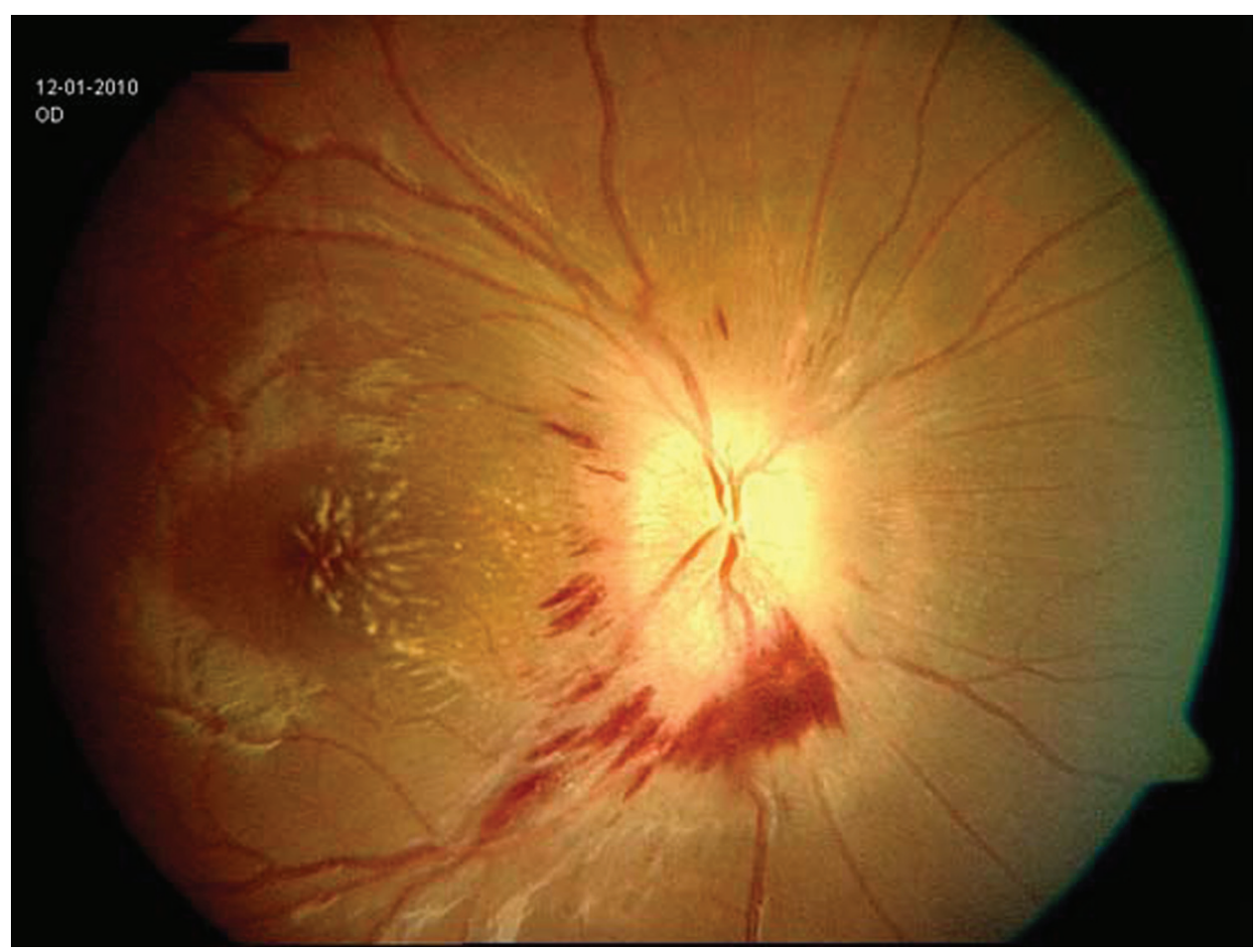

Figure 1 Right fundus image shows peripapillary yellowish infiltrates and haemorrhages. 


\section{BMJ Case Reports}

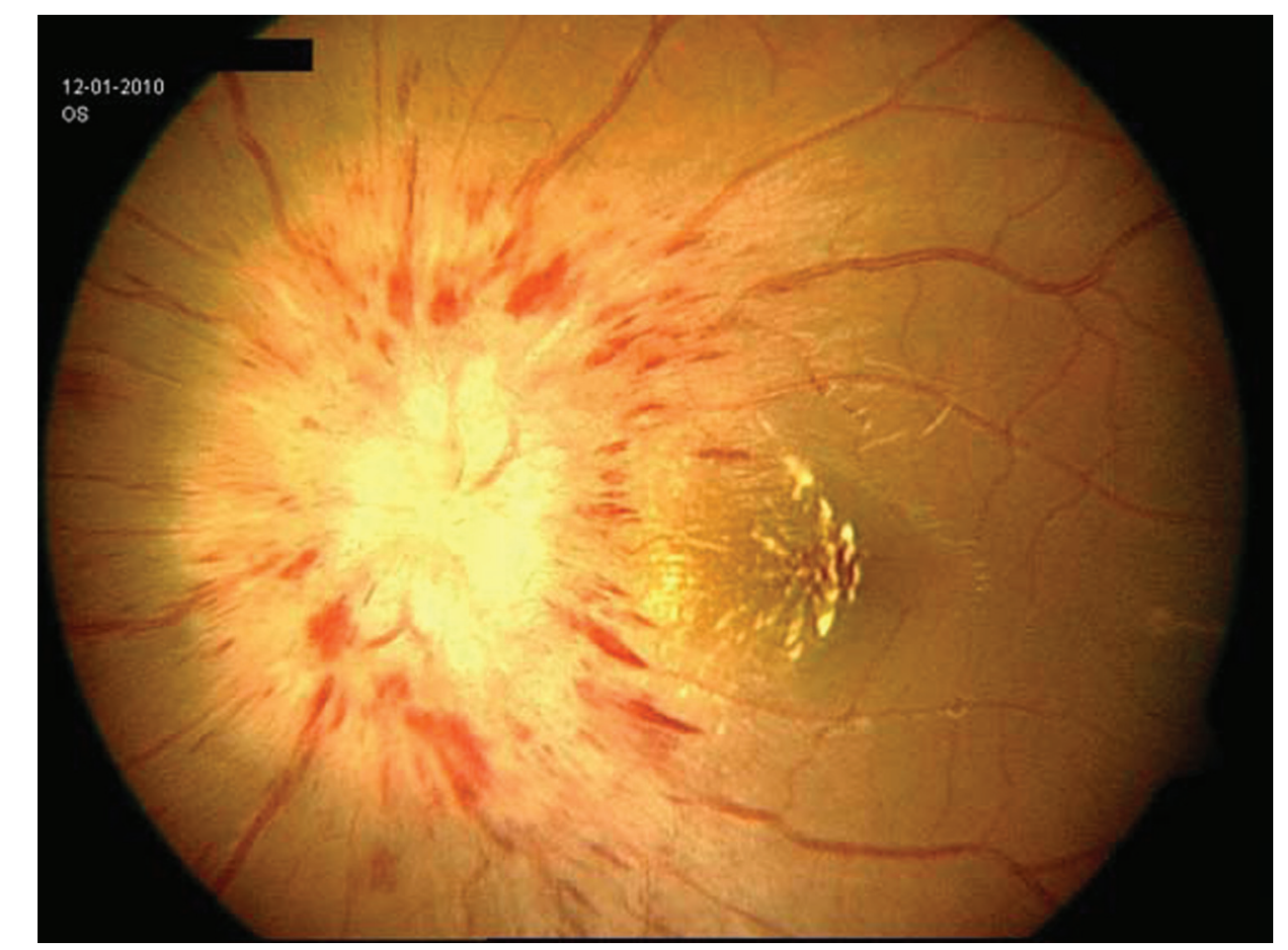

Figure 2 Left fundus image shows peripapillary yellowish infiltrates and haemorrhages.

This pdf has been created automatically from the final edited text and images.

Copyright 2011 BMJ Publishing Group. All rights reserved. For permission to reuse any of this content visit http://group.bmj.com/group/rights-licensing/permissions.

BMJ Case Report Fellows may re-use this article for personal use and teaching without any further permission.

Please cite this article as follows (you will need to access the article online to obtain the date of publication).

Peyman M, Hieng TLN, Subrayan V. Optic nerve involvement as a first manifestation of acute lymphoblastic leukaemia after remission. BMJ Case Reports 2011;10.1136/bcr.11.2010.3517, date of publication

Become a Fellow of BMJ Case Reports today and you can:

- Submit as many cases as you like

Enjoy fast sympathetic peer review and rapid publication of accepted articles

- Access all the published articles

- Re-use any of the published material for personal use and teaching without further permission

For information on Institutional Fellowships contact consortiasales@bmjgroup.com

Visit casereports.bmj.com for more articles like this and to become a Fellow 